\title{
Response of the parasitic plant (Striga hermonthica) seeds to different germination stimulants produced by sesame and pigeon pea varieties
}

\author{
Ahom, R.I and Magani, I.E. \\ Department of Crop and Environmental Protection, University of Agriculture, P.M.B. 2373, \\ Makurdi Nigeria, *Corresponding author E-mail:- $\underline{\text { m.enochistifanus@yahoo.com }}$

\begin{abstract}
The experiments were conducted in the Pathology Laboratory of the University of Agriculture, Makurdi $\left(07^{\circ} \mathrm{E} 14^{\prime} \mathrm{N}, 08^{\circ} 38^{\prime} \mathrm{E}\right)$ with the principal objective to evaluate sesame and Pigeon pea genotypes in their ability to stimulate germination of $S$. hermonthica seeds. The treatments consist of 17 and 13 varieties of Sesame and Pigeon pea, respectively. These varieties were screened in a completely randomized design (CRD) with four replications. There were significant differences among the varieties of Sesame and Pigeon pea in respect to relative germination percentage. In sesame, higher relative germination of $47.8 \%$ and $30.4 \%$ were recorded with variety $69 \mathrm{~B}-882$ and Yandev 55, respectively. The relative germination of $16-28 \%$ was recorded by varieties: - Ex-Pankshin - 98, 73A-79B, Cross-95, E-8, Ncriben -01M, 73A- 892B, 60-2-3-1$8 \mathrm{~B}$, and Ciano-16. The 17 sesame varieties were grouped in four (4) based on their efficacy to stimulate seed germination of S. hermonthica: High (69B-882 and Yandev 55), Moderate (ExPankshin -98, 73B, Cross-95, E-8, Ncriben-01M, 73A-82B, 60-2-3-1-8B and Ciano-16); low (Yandev-75, Type-4, Ciano - 27, Eva and 69-1-1); Very low (Pachequeno, Ncriben-03L), respectively. But in the Pigeon pea accessions, the percentage germination of Striga seeds was highest with TCC 1035, Cita 4, TCC 6, TCC 8126, Cita 3, TCC 87 and Cita 2 (in descending order, 4.03 to $3.05 \%$ ). These were followed by TCC2, TCC 8129, TCC 151 and Cita1 (2.99 to 2.06\%) and the TCC8 and TCC 8129 (1.74 and 0.76\%). The two test crops (sesame and Pigeon pea), the two controls, (GR - 24 and water) recorded the highest and lowest germination percentages, respectively. In the two varieties, the high and moderate stimulant producers can be used as good trap varieties. There is the need to screen more sesame and Pigeon pea genotypes to increase the potential for use of this control strategy.
\end{abstract}

Keywords: Intercrop; Seed bank, sesame, Pigeon pea genotype, Striga hermonthica Germination.

\section{INTRODUCTION}

Striga hermonthica (Del.) Benth of the genus Striga (Scrophulariaceae) is endemic in the African Savannas where it parasitizes cultivated crops such as maize, millet, sorghum, rice, sugarcane as well as pasture and wild grasses (Parker and Riches, 1993; Weber et al., 1995). It is the dominant parasitic weed species in the Nigerian Savanna, occurring in ecological zones extending from latitudes $7-14 \mathrm{~N}^{0}$. It is one of the major threats to cereal production where severe damage can cause total crop loss in farmers' fields particularly under low fertility conditions (Lagoke et al., 1991; Ogungbile et al., 1998; Kim el al., 2002, Marley et al., 2004).

Precious research has identified effective control technologies (Parker and Riches, 1993) that include planting resistant host crop cultivars, using leguminous trap crops, and improving and maintaing soil fertility (Kim et al., 1997; Debra et al., 1998;
Sauerborn, 1999; Schulz et al., 2003); chemical herbicides (Ariga and Berner, 1993) and biological control (Marley et al., 1999). However, for most African cereal growers, the most appropriate method would be one that uses a simple and inexpensive technique adapted to their farming systems. One such simple, yet promising control method, is the use of non-hosts or trap crops. These crops have root exudates that stimulate Striga seeds to germinate but the germinated Striga plants cannot parasitize them. Hence when used as components of cropping systems, such trap crops have led to considerable reduction in Striga seed bank and infestation (Kroschel and Sauerborn, 1988).

Sesame or Soybean has been identified as one of the most effective trap crops of $S$. hermonthica (Kroschel and Sauerborn, 1988). However, a large variability exists among the sesame or soybean cultivars with respect to this trait (Alabi et al., 1994, Berner et al., 1994). Sesame and pigeon pea is 
rapidly expanding in Nigeria, in areas where mixed farming, intercropping and crop rotation are the common farming systems. Varieties with effective trap -crop capacity will provide farmers with a cheap tool to fight the Striga menace. This will increase cereal crop yield, improve food security and economic status of farmers. Therefore the principal objective of this study was to screen sesame and pigeon pea varieties in their ability to stimulate germination of $S$. hermonthica strains in Benue State of Nigeria.

\section{MATERIALS AND METHODS}

The in-vitro experiments were conducted in the Pathology Laboratory of the University of Agriculture, Makurdi in 2007/2008 after preliminary tests in IITA, Kano Striga Laboratory. The sesame (17) varieties were obtained from the National Cereal Research Institute (NCRI) Badeggi, Bida, Nigeria, while Pigeon pea (13) varieties were obtained from IITA, main station, Ibadan. The trial was to assess the variability among the genotypes of sesame and pigeon pea in their ability to stimulate germination of $S$. hermonthica seeds. The "cut-root method" procedure described by Berner et al (1997) was used. In the two trials, a completely randomized design (CRD) was used with four replications.

\section{Procedure of the Cut- root Technique}

Sterilization (surface disinfection) of seeds: The sesame, pigeon pea and germinable Striga seeds were sterilized with $1 \%$ solution of sodium hypochlorite which was made by adding $1 \mathrm{ml}$ of $10 \%$ sodium hypochlorite to $99 \mathrm{mls}$ of sterile deionized water. Sterilization of test crop seeds was done for each variety separately. Thirty milliliters $(30 \mathrm{mls})$ of the constituted solution was poured onto the seeds in separate beakers stirred to mix thoroughly and left to stand for five minutes. After this, the solution was drained of together with floating seeds and debris. Clean distilled water was then added to the seeds and the mixtures were poured into funnels lined with filter paper. The seeds were left to dry overnight. All filter papers containing seeds for drying were properly labeled. After drying, the Striga seeds were ready for pre-conditioning and the crop seeds ready for planting.

Pre-conditioning of Striga seeds: Small disks of glass fibre paper made by standard punch were put in a wide Petri-dish and wetted with distilled water. Between n 180 and 220 disks were arranged in $9 \mathrm{~cm}$ Petri dish for conditioning. Two pieces of $11 \mathrm{~cm}$ ordinary filter paper were placed in a sterilized $11 \mathrm{~cm}$ dish and moistened with distilled water. The moist disks were picked with sterilized forceps and arranged in circles to cover the moistened filter paper in the Petri dishes. The sterilized Striga seeds were then dabbed on the pre-arranged glass fibre disks in the Petri dish. These dishes were then wrapped in aluminium foil sheets to exclude light and kept in the incubator at a temperature of $28^{\circ} \mathrm{C}$ for conditioning for two weeks (14 days) in the dark.

On the same day, plastic pots (15- $20 \mathrm{~cm}$ diameter) were filled with $1 \mathrm{~kg}$ each of top soil, watered and labeled. Sterilized seeds of the test crop varieties were planted at $2 \mathrm{~cm}$ depth in accurately labeled pots. After planting, the seeds were allowed to grow for two weeks, after which seedlings were harvested for the experiments. Watering was done as required during this period.

Set up of the experiment: After conditioning Striga seeds and growing test crop seedlings for two weeks, the experiment was set up as follows: - The Sesame and Pigeon pea seedlings were harvested with care taken not to dislodge the roots. Soil was carefully and thoroughly washed off the roots with running tap water. The roots were then put in a Petri dish and wetted to keep them from drying out and brought into the laboratory. Before this, sterilized $9 \mathrm{~cm}$ Petri dishes were lined with double layer $9 \mathrm{~cm}$ Whatman filter paper moistened with distilled water and $2 \mathrm{~cm}$ diameter aluminium foil ring placed in the centre of the moistened filter paper in the Petri dish. The preconditioned Striga seeds on the microfibre glass disks were removed from the incubator and with a sterilized forceps; disks containing pre-conditioned Striga seeds were picked and arranged in four rows on the double layer moist Whatman filter paper. The roots of the 14 day old seedlings of the test crops were cut into tiny pieces (about $1 / 2 \mathrm{~cm}$ in length) with a sterile surgical blade and $1 \mathrm{~g}$ root pieces weighted out from each variety, wrapped in separate aluminium foil were placed in the centre of the Petri dishes. Using a micropipette, $300 \mu$ l of distilled water were added to the roots to provide enough wetting to enable diffusion of root exudates across the filter paper to the Striga seeds. In other Petri dishes, the roots were replaced with either $300 \mu \mathrm{l}$ of a chemical stimulant, GR-24, one of the Strigol analogues, which triggers germination of $S$. hermonthica seeds, or sterile deionized water. These represented the positive and negative controls, respectively. All the Petri dishes were correctly labeled and sealed with parafilm ' $M$ ' as soon as the stimulant was introduced. 
The Petri dishes were then wrapped in aluminium foil and incubated at $28^{\circ} \mathrm{C}$ for 72 hours in the dark.

\section{Data collection and Analysis}

After 72 hours, the Petri dishes were removed from the incubation and viewed under a dissecting microscope. Both germinated and ungerminated Striga seeds were counted. From the data collected, the following were calculated:

$\begin{array}{ll}\text { (a) } & \begin{array}{l}\text { Actual percentage germination of S. hermonthica } \\ \text { seeds by test crop variety (\%) or GR }-24(\%)\end{array} \\ = & \frac{\text { Number of germinated seeds }}{\text { Total number of seeds incubated }} \times 100 \\ \text { (b) } & \text { Relative germination } \\ = & \frac{\text { Actual percentage germination (\%) }}{\text { Actual percentage germinated with GR- } 24}\end{array}$

The data collected were square-root transformed and analyzed using Genstat 5 Release 3.2 Analysis of variance and mean separation was done using FL.S.D at $1 \%$ level of significance.

\section{RESULTS AND DISCUSSION}

There were significant differences $(P<0.001)$ among the varieties of sesame screened in their ability to stimulate in-vitro seed germination in S. hermonthica (Table 1). The relative germination percentage was higher in variety 69B-882 and Yandev 55 (47.8\% and $30.4 \%)$ than that of Ex-Pankshin - 98, 73A - 79B, Cross -95, E-8, Ncriben - 01M, 73A - 82B, 60-2-3$18 \mathrm{~B}$, and Ciano-16 (ranging between 17-28 \%) which were in turn higher than Yandev - 75, Type-4, higher than those of Pachequeno and Ncriben - 03L (less than 7\%). GR-24 and water gave the highest and lowest germination percentage (\%) of Striga seeds, respectively. Similarly, the percentage germination of $S$. hermonthica seeds by pigeon pea accessions was significantly different $(P<0.001)$ with set and accession (Table 3). The considerable variability observed between and within the pigeon pea and seame varieties screened in this study confirms the earlier reports by several other workers of the variation among trap crop varieties in their ability to stimulate germination of $S$. hermonthica seeds using cut-root assay or technique (Alabi et al., 1994; Ariga, 1996; Berner et al., 1996; Dashiell et al., 1999). As expected, GR-24 and sterile deionized water gave the highest and lowest percentage seed germination in S. hermonthica. However, contrary to expectation, sterile deionized water (negative control) germinated a few Striga seeds occasionally during the study. The germinated seeds may have been attached to tiny root pieces of cereals harvested with Striga plants from which seed samples were collected and were not removed during cleaning process.

In the Sesame two sets (runs) of experiment, the set two (2) had a superior percentage of seed germination (14.1\%) when compared to set one (1) of (4.1\%) on the average. The interaction between set and variety was also highly significant $(P<0.001)$. The test crop varieties differed in performance with set. In set $1,73 \mathrm{~A}$ - 79B produced the highest quantity of germination stimulant (3.6\%) followed by Type-4 (3.0\%) and the least was 69B- 882 with almost $0.0 \%$ stimulation (0.1). However, in set 2, 69B -882 gave the highest percentage germination of $S$. hermonthica seeds (34.5\%). The percentage stimulant production of Eva and 69 -1-1 was generally low and did not vary too much with set. GR24 and water constantly produced the highest and lowest percentage germination of Striga seeds, respectively in both sets.

But in the Pigeon pea accessions, the second set had a superior performance (3.61) (3.6\% actual germination) as compared to set 1 and 3 (2.1 and $2.8 \%$, respectively). Set three (3) also gave a significantly higher performance than set 1 (Table 3 ). There was significant difference germination in Striga. Using the values is set 2 , the percentage germination of Striga seeds was highest with TCC 1035, Cita 4, TCC 6, TCC 8126, Cita 3, TCC 87 and Cita 2, (in descending order, 4.03 to $3.05 \%$ ). These were followed by TCC 2, TCC 81289, TCC 151 and Cita 1 (2.99 to 2.06\%) and then TCC 8 and TCC 8129 (1.74 and 0.76\%). GR- 24 (positive control and water (negative control) recorded the highest and lowest germination percentages, respectively. That the percentage germination of Striga seeds by cutroot pieces of test crops varied significantly between runs in this study may be due to prevailing environmental conditions at the time of the setting up the experiment. Although the trap crop varieties were not as effective as GR-24 (chemical stimulant) in stimulating Striga seed germination, involving them in intercrop may be a practical way to reduce Striga effect in maize for the small-scale African farmer. The roots of trap crops produce germination stimulants that induce endogenous ethylene production within Striga seeds (Logan \& Stewart, 1991; Babiker et al., 1993) and cause them to germinate in the absence of the host, and therefore die within a few days after emergence (fatal or suicidal germination). 
On the basis of their efficacy to stimulate seed germination of $S$. hermonthica, the pigeon pea and Sesame varieties tested may be grouped into three and four high, moderate low and very low stimulant production respectively, as shown in Tables $2 \& 4$ and figures $1 \& 2$. For the 17 Sesame varieties, the high stimulant producers include :- $(69 \mathrm{~B}-882$ and Yandev - 55) ; moderate :- (Ex- Pankshin-98, 73A79B, Cross-95, E-8, Ncriben - 01M, 73A -82B, 60-22-1-8B and Ciano-16) ; low:- (Yandev-75, Type-4, Ciano-27, Eva and 69 -1-1)., very low:- (Pachequeno and Ncriben - 03L), respectively. In the Pigeon pea, the very high stimulant producers include :- (TCC 1035, Cita 4, TCC 6, TCC 8126, Cita 3, TCC 87 and Cita 2)., high stimulant:- (TCC 2, TCC 8127, TCC 151 and Cita 6); moderate :- (TCC 8 and TCC 8129), respectively. The varieties of Sesame and Pigeon pea selected as good trap crops in this study can be used in the field to reduce the seed bank of $S$. hermonthica in the soil in Benue State. Moreover, cowpea and soybean cultivars selected for their efficacy in stimulating germination of Striga seeds using cut-root assay have been used in the field by other workers to effectively reduce $S$. hermonthica parasitism on sorghum and maize (Doggett, 1984; Ariga, 1996; Berner et al., 1996; Singh, 2000). Ariga (1996) found the ranks of soybean cultivars he worked with fairly consistent in germinating $S$ hermonthica seeds collected from three different locations in Nigeria Stimulate high germination of Striga at another location. Nonetheless, strain variation in S. hermonthica has been widely reported. In this study, the varieties of Sesame and Pigeon pea selected, as high stimulant producers need to be further investigated with $S$. hermonthica strains from other locations in Nigeria reach a similar conclusion.

Table 1: $\quad$ Germination of S. hermonthica seeds by cut-root pieces of sesame varieties, GR - 24 and water (Square - root transformed values $\sqrt{ } \mathrm{Y}+0.5$ of actual counts).

\begin{tabular}{|c|c|c|c|c|c|c|}
\hline \multirow[t]{3}{*}{ Variety } & \multicolumn{3}{|c|}{ Actual Germination (\%) } & \multicolumn{3}{|c|}{ Relative Germination (\%) } \\
\hline & \multicolumn{2}{|c|}{ Set (Run) } & \multirow[t]{2}{*}{ Mean } & \multicolumn{2}{|c|}{ Set } & \multirow[t]{2}{*}{ Mean } \\
\hline & 1 & 2 & & 1 & 2 & \\
\hline Ciano - 16 & $1.44(1.6)$ & $3.59(12.6)$ & $2.51(5.8)$ & $1.58(2.0)$ & $4.20(17.4)$ & $2.89(7.9)$ \\
\hline Ciano - 27 & $0.98(0.5)$ & $3.39(11.6)$ & $2.91(8.0)$ & $1.02(0.5)$ & 3.97(16.0) & $2.50(5.8)$ \\
\hline Cross - 95 & $1.41(0.8)$ & $4.04(16.3)$ & $1.55(1.9)$ & $4.75(22.1)$ & $4.75(23.2)$ & $3.15(9.4)$ \\
\hline$E-8$ & $1.17(0.9)$ & $4.26(17.8)$ & $2.72(6.9)$ & $1.29(1.2)$ & $4.98(24.6)$ & $3.14(9.4)$ \\
\hline Ex-Pankshin - 98 & $1.24(1.0)$ & $4.51(20.03)$ & $2.87(7.9)$ & $1.36(1.3)$ & $5.29(28.1)$ & $3.33(10.6)$ \\
\hline Eva & $1.64(2.2)$ & $2.27(4.9)$ & $1.95(3.3)$ & $1.83(2.8)$ & $2.61(6.7)$ & $2.22(6.9)$ \\
\hline Ncriben - 03L & N.T & $1.93(4.3)$ & $1.93(3.2)$ & N.T & $2.18(4.3)$ & $1.44(1.6)$ \\
\hline Ncriben - 01M & $1.8(2.3)$ & $3.63(13.1)$ & $2.65(6.5)$ & $2.00(3.5)$ & $4.12(18.7)$ & $3.06(8.9)$ \\
\hline Pachequeno & N.T & $1.42(4.6)$ & $1.42(1.5)$ & N.T & $2.45(6.2)$ & $1.58(2.0)$ \\
\hline Type - 4 & $1.84(2.9)$ & $2.62(6.5)$ & $2.23(4.5)$ & $2.00(3.5)$ & $3.07(9.3)$ & $2.55(6.0)$ \\
\hline Yandev 55 & $1.43(1.5)$ & $4.71(22.1)$ & $3.07(8.9)$ & $1.56(1.9)$ & $5.50(30.4)$ & $3.53(12.0)$ \\
\hline Yandev 75 & $1.60(2.1)$ & $2.93(8.3)$ & $2.26(4.6)$ & $1.75(2.6)$ & $3.40(11.4)$ & $2.58(6.2)$ \\
\hline $60-2-3-1-8 B$ & $1.33(1.3)$ & $3.76(13.9)$ & $2.55(6.0)$ & $1.46(1.6)$ & $4.37(18.7)$ & $2.91(8.0)$ \\
\hline $69-1-1$ & $1.26(1.1)$ & $2.37(5.3)$ & $1.82(2.8)$ & $1.39(1.4)$ & $2.76(7.5)$ & $2.07(3.8)$ \\
\hline $69 B-882$ & $0.81(0.2)$ & $5.90(34.5)$ & 3.36(10.8) & $0.83(0.2)$ & $6.92(47.8)$ & $3.87(15.0)$ \\
\hline $73 A-79 B$ & $2.02(0.6)$ & $3.71(13.3)$ & $2.86(7.7)$ & $2.27(4.7)$ & $4.32(18.7)$ & $3.29(10.3)$ \\
\hline $73 A-82 B$ & $1.40(1.5)$ & $3.83(14.6)$ & 2.61(6.3) & $1.52(1.8)$ & $4.47(20.0)$ & $3.00(8.5)$ \\
\hline \multicolumn{7}{|l|}{ Controls } \\
\hline$G R-24$ & $8.90(78.7)$ & $8.56(73.0)$ & $8.73(75.7)$ & $10.02(100)$ & $10.02(100)$ & $10.02(100)$ \\
\hline Water & $0.71(0.0)$ & $0.86(0.3)$ & $0.76(0.12)$ & $0.71(0.0)$ & $1.51(0.7)$ & $1.11(0.7)$ \\
\hline Mean of Set & $1.76(2.6)$ & $3.57(12.2)$ & $2.6(6.6)$ & $3.15(14.1)$ & $3.82(14.1)$ & \\
\hline
\end{tabular}

Actual\% germination

F-L.S.D (0.01) for comparing main effect of set $=0.17$

F-L.S.D $(0.01)$ for comparing main effect of variety $=0.51$

F-L.S.D ${ }_{(0.01)}$ for comparing main of set $x$ variety $=0.73$

Relative \% germination

F-L.S.D ${ }_{(0.01)}$ for comparing main effect of set $=0.23$

F-L.S.D ${ }_{(0.01)}$ for comparing main effect of variety = 0.69

F-L.S.D $(0.01)$ for comparing main of set $x$ variety = 0.98

The values in parenthesis are the actual\% germination of Striga seeds

By cut- root pieces of sesame varieties in set 2 .

NT $=$ Not tested 
Agric. Biol. J. N. Am., 2010, 1(6): 1199-1205

Table 2: Grouping of sesame varieties on the basis of their efficacy to stimulate seed germination in $S$. hermonthica

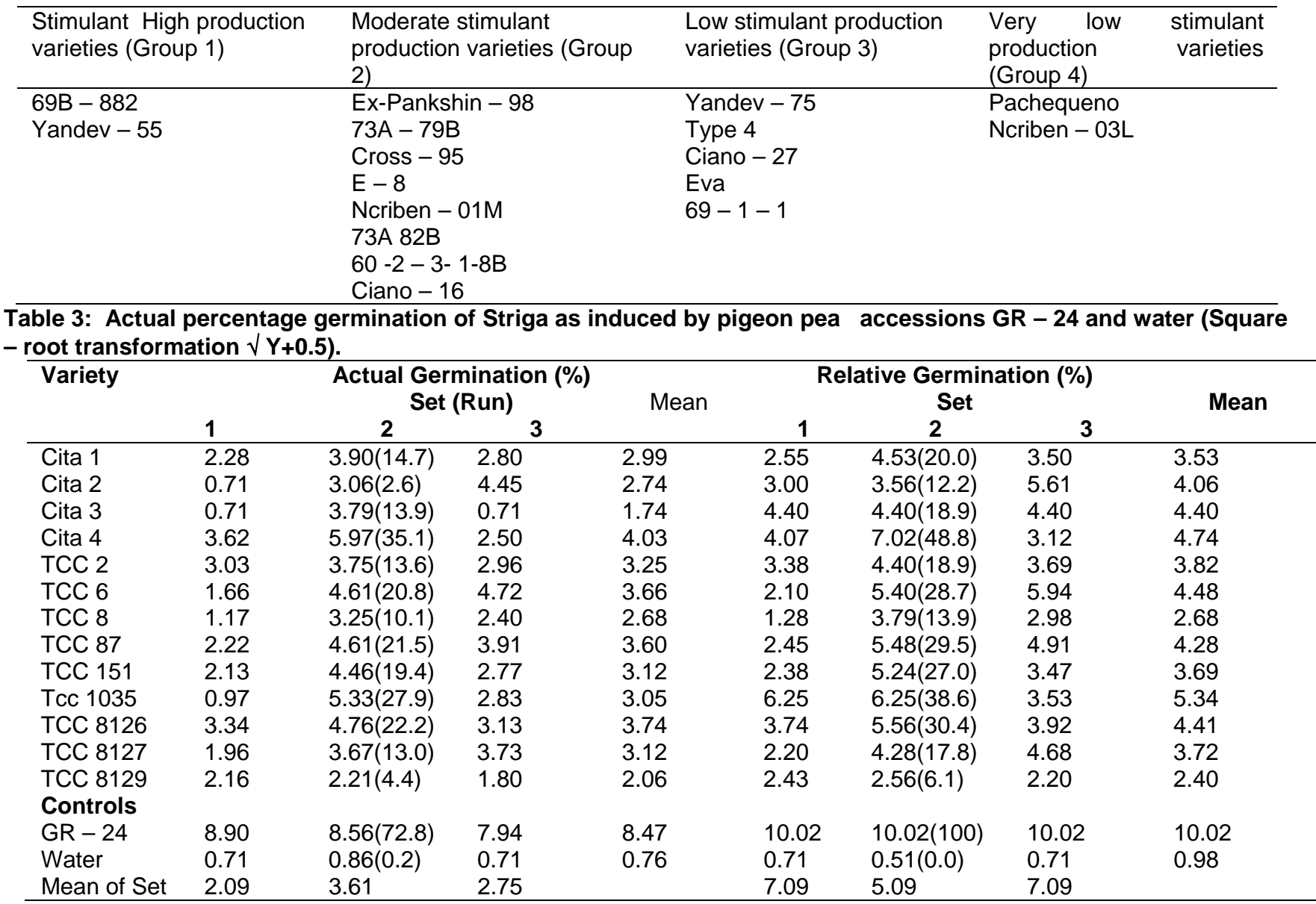

\section{For actual percentage germination}

F-L.S.D $(0.01)$ for comparing main effect of set $=0.17$

F-L.S.D $(0.01)$ for comparing main effect of variety $=0.41$

F-L.S.D $(0.01)$ for comparing set $x$ variety interaction $=\quad 0.70$

Relative \% germination

F-L.S.D ${ }_{(0.01)}$ for comparing main effect of set $=0.27$

F-L.S.D $(0.01)$ for comparing main effect of variety $=0.58$

F-L.S.D $(0.01)$ for comparing set $x$ variety interaction $\quad=\quad 1.0$

The values in parenthesis are the actual\% germination of $S$ hermonthica seeds as induced by cut roots of pigeon pea accessions.

Table 4: $\quad$ Grouping of pigeon pea accessions on the basis of their efficacy to stimulate seed germination in S. hermonthica

\begin{tabular}{lll}
\hline $\begin{array}{l}\text { Very high stimulant production } \\
\text { varieties (Group 1) }\end{array}$ & $\begin{array}{l}\text { High stimulant production } \\
\text { varieties (Group 2) }\end{array}$ & $\begin{array}{l}\text { Moderate stimulant production varieties } \\
\text { (Group 3) }\end{array}$ \\
\hline TCC 1035 & TCC 2 & TCC 8 \\
Cita 4 & TCC 8127 & TCC 8129 \\
TCC 6 & TCC 151 & \\
TCC 8126 & Cita 1 & \\
Cita 3 & & \\
TCC 87 & & \\
Cita 2 & & \\
\hline
\end{tabular}




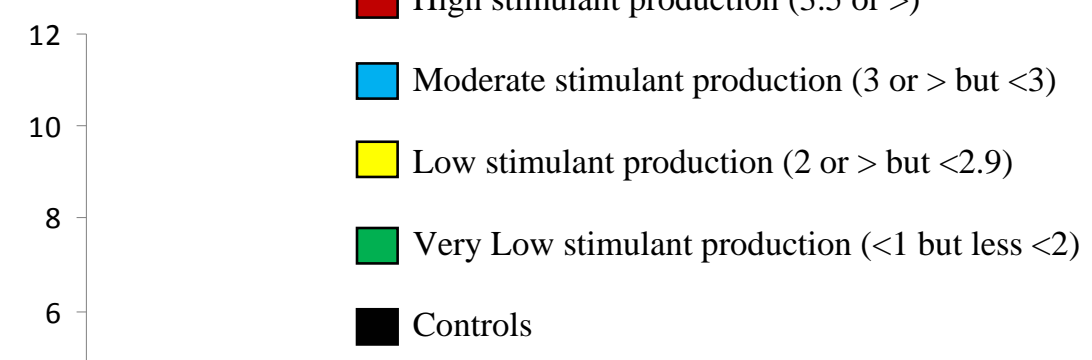

4

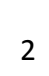

0

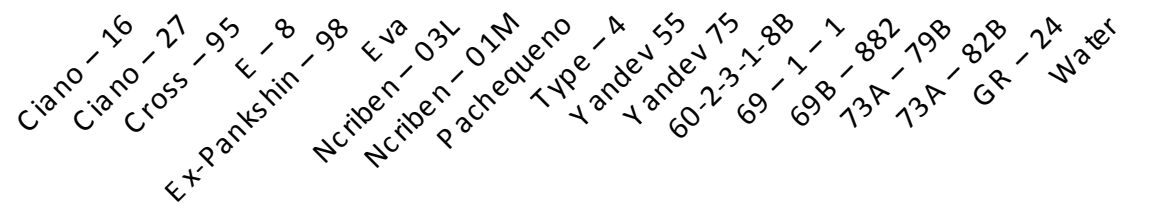

Sesame Varieties

Fig 1. Variation among sesame varieties in abilities to germinate $S$. hermonthica seeds

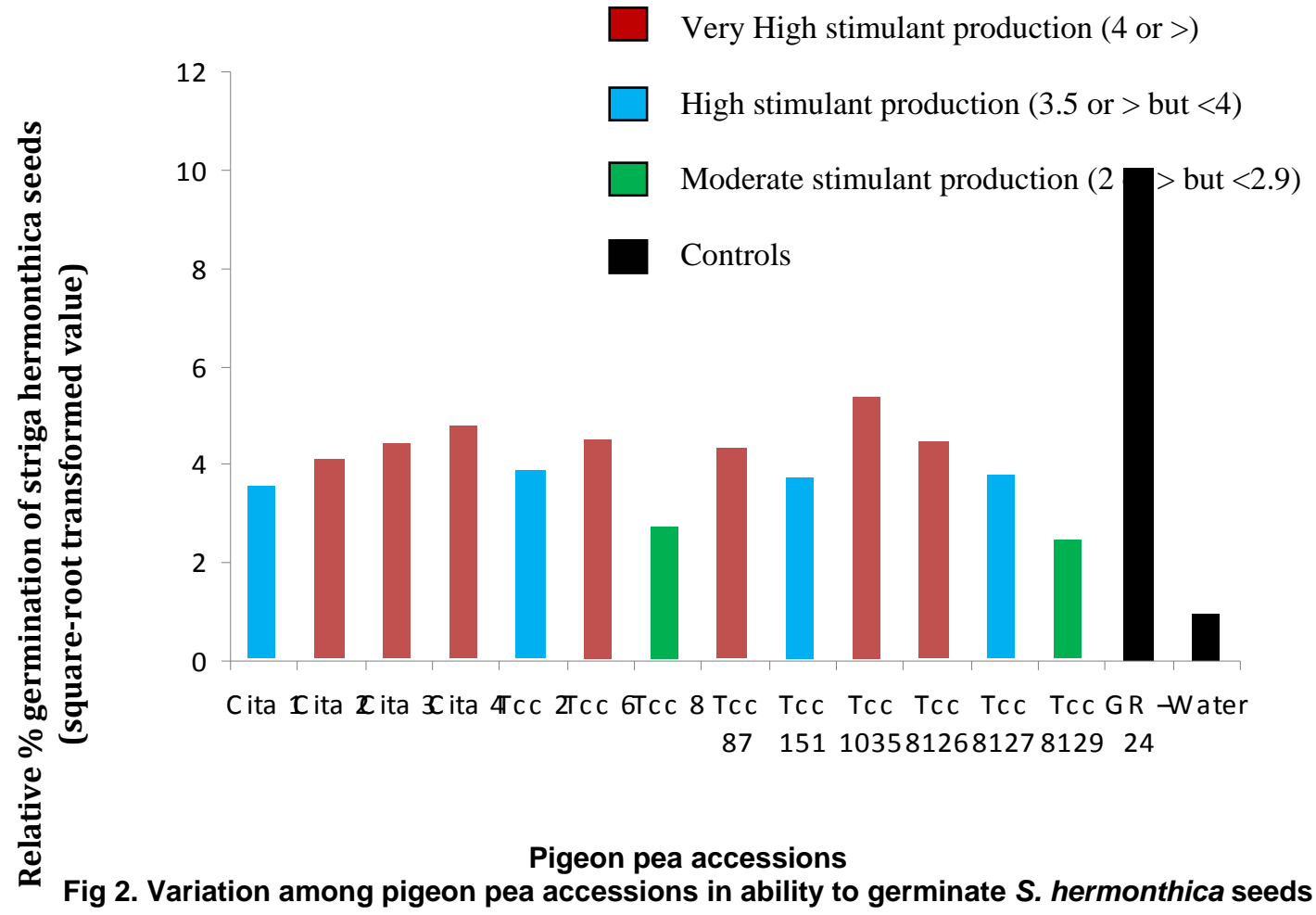




\section{REFERENCES}

Alabi, M.O., Berner, D.K.and Olaniyan, G.O. (1994). Characterization of Soybean cultivars for Striga hermonthica control. Phytopathology 84 (10): 1151

Ariga, E. (1996). Bioassay of germination stimulants of Striga hermonthica .PhD. Thesis, University of Nairobi. 129 pp.

Babiker, A.G. T., Ejeta, G., Butler, L.G. and Woodson, W.R. (1993). Ethylene biosynthesis and Strigolinduced germination of Striga asiatica. Physiological Plantarum 88: 359- 365.

Berner, D. K., Carsky, R.J., Dashiell, K.E., Kling, J.G. and Manyong, V.M. (1996). A land management based approach to integrated Striga hermonthica control in Sub-saharan Africa. Out look on Agriculture 25 (3): 157- 164.

Berner,D.K., Kling, J.K. and Singh, B.B. (1996).Striga Research and Control. A perspective from Africa. Plant Diseases 79: 652-660

Dashiell, K.E., U.di Umba, J., Kling, J.G. and Berner, D.K. (1999). Breeding for integrate management of Striga hermonthica. Paper presented at the Workshop on Breeding for Striga resistance in cereals, 16-20 August, 1999, II TA, Ibadan, Nigeria. 10pp.

Debra, S.K., Defoer, T. and Bengaly, M. (1998). Integrating farmers' knowledge, attitude and practice in the development of sustainable Striga control interventions in Southern Mali. Netherlands Journal of Agricultural Science 46: 65-75.

Doggett, H. (1984). Striga . Its biology and control an overview. In: E.S. Ayensu, H. Doggett, R.D. Keynes, L.J. Musselman, T. Marton - Lefevre, C. Parker and A. Pickering (eds). Striga Biology France and the Int. Dev. Res. Ctr. Ottawa, Canada. pp. 27-36.

Kroschel, J. and Sauerborn, J. (1988). Training Manual for course on Biology and control of parasitic weeds. University of Hohenheim, Germany.

Kim, S.K., Adetimirin, V.O. and Akintunde, A.Y. (1997). Nitrogen effects of on Striga hermonthica infestation, grain yield and agronomic traits of tolerant and susceptible maize hybrids. Crop Science 37: 711-716

Kim., S.K., Adetimirin, V.O., The C. and Cossou, R. (2002). Yield losses in maize due to Striga hermonthica in West and Central Africa. International Journal of Pest Management 48: 211-217.

Lagoke, S.T.O., Parkinson, V. and Agunbiade, R.M. (1991). Parasitic Weeds and control methods in Africa. In: K.S. kim (ed). Combating Striga in Africa. Proceedings of the International Workshop Organized by IITA, ICRISAT and IDRC, August 22-24 IITA, Ibadan, Nigeria, pp 5-14

Logan, D.C. and Stewart, G.R. (1991). Role of ethylene in the germination of hemi-parasite Striga hermonthica. Plant Physiology 92: 1435-1438

Marley, P.S., Ahmed, S.M., Shebayan, J.Y. and Lagoke, S.T.O. (1999). Isolation of Fusarium oxysporum with potential for biocontrol of the witch weed (Striga hermonthica ) in the Nigerian Savanna. Biocontrol Science and Technology 9:159-163.

Marley, P.S., Toure, A., Shebayan, J.Y., Aba, D. A., Toure, O.A., Diallo, G.A. and Katile, S.O. (2004). Variability in host plant resistance of sorghum to Striga hermonthica infestation in the West Africa. Archives of phytopathology and Plant Diseases 37: 29-34.

Ogungbile, A.D., Tabo, R., Vanduivenbooden, $\mathrm{N}$ and Debra, S.K. (1998).Analysis of constraints to Agricultural production in the Sudan Savanna zone of Nigeria using multi-scale characterization. Netherlands Journal of Agricultural Science 48:27-38

Parker, C.and Riches, C.R. (1993).Parasitic Weeds of the World: Biology and Control. Wallingford, Oxon, UK: CAB International, pp. 304.

Sauerborn, J. (1999). Striga biology versus control. In: J. Kroschel, H. Mercer-Quarshie and J. Sauerborn (ed) . Advances in Parasitic weed control at on farm level, Vol. 1, Joint action to control Striga in Africa. Margraf Verlag, Weikersheim, Germany.

Schulz, S., Hussaini, M.A., Kling, J.G., Berner, D.K. and Ikie, F.O. (2003). Evaluation of integrated Striga hermonthica control technologies under farmer management. Experimental Agriculture 39:99-108

Singh, B.B. (2000). Breeding cowpea varieties with combined resistance to different strains of Striga gesnerioides. In: B.I.G. Haussman, D.E. Hes, M.I. Koyama, L. Grivet, H.F.W. Rattunde, and H.A. Geiger (eds).Breeding for Striga resistance in cereals. Proc. of a Workshop held at IITA, Ibadan, Nigeria.18-20 August., 1999, P. 261-270.

Weber, G.K., Elemo, K.A., Awad. A. Lagoke. S.T.O. and Oikeh, S. (1995). Striga hermonthica in cropping system of the Northern Guinea Savanna. Resources and Crop Management Monograph No. 19, IITA, Ibadan, Nigeria. 